\title{
When do the economic aspect and ecology policies defend health of mariners?
}

\author{
\begin{tabular}{c}
\hline Richard Pougnet ${ }^{\mathbf{1 , 2}}$, Laurence Pougnet ${ }^{\mathbf{1 , 3}}$, David Lucas $^{\mathbf{1 , 4}}$, Luisa Canals $^{\mathbf{5 , 6},}$, \\
Jean-Dominique Dewitte ${ }^{\mathbf{1 , 2}}$, Brice Loddé $^{\mathbf{1 , 2}}$ \\
${ }^{1}$ French Society of Maritime Medicine (SFMM), France \\
${ }^{2}$ Centre of Occupational and Environmental Diseases, Teaching Hospital of Brest, France \\
${ }^{3}$ Military Hospital, Clermont-Tonnerre, Brest, France \\
${ }^{4}$ Occupational Diseases Centre, Brest Harbour, France \\
${ }^{5}$ Spanish Society of Maritime Medicine (SEMM), Tarragona, Spain \\
${ }^{6}$ International Maritime Health Association Research Chair \\
\hline
\end{tabular}
}

Seamen can develop many pathologies: respiratory diseases, cutaneous diseases, cancer, joint pathologies etc. Several studies have shown the significant risk of cancer to seamen, particularly in engineers [1]. There are several reasons for these cancer risks.

Seamen worked for a long time at the edges of boats containing asbestos. This explains a number of lung cancer and the mesothelioma [2]. Regulations have evolved in many countries. In France, for example, the use of asbestos in construction was banned in 1996. We can assume that over time this risk of asbestos-exposure cancer will go down and disappear.

Unfortunately, there are other carcinogens on ships. Polycyclic aromatic hydrocarbons (PAHs) are also carcinogenic. They also have neurological toxicity during acute poisoning. Therefore, seamen are still exposed, particularly in engine rooms [1]. What can be done to reduce this exposure?

Developments of an ecological economy could reduce these exposures. Indeed, we are witnessing the emergence of new, greener technologies in maritime transport (https://www.meretmarine.com/fr/content/fairtransport-relance-le-commerce-maritime-la-voile). The goal of these new technologies is to reduce global warming of the Earth (http:// www.bretagne-info-nautisme.fr/fr/actualites/actualites/unnouveau-bateau-pour-transporter-feves-de-cafe-et-cacao). Several manufacturers are developing wind powered ships.

What are the consequences for the health of seamen?

They will work less at engine rooms. There will be less $\mathrm{PAH}$ and exhaust emissions. Seamen will be less exposed.
It is logical to presume that the risks of acute intoxication and cancer will be reduced.

Nevertheless, these new technologies will not solve all the occupational health problems of seamen. The exploitation of certain resources will always expose seafarers to other carcinogens [3]. The transported goods, or their treatment, will always expose the seamen to risks, such as poisoning [4]. Seamen will always be exposed to risk of infection, especially during a stopover [5].

On the other hand, new occupational health issues may arise. For example, will the new materials themselves have health effects? Will shipbuilding workers be affected by other diseases? As for the seamen who sail on these boats, will they have new pathologies? We know, for example, that seamen have a lot of accidents at work [1]. New tasks on these wind-powered ships may have an impact on the frequency of accidents.

Finally, there is a question of social justice. Indeed, in Europe, there is a considerable social class gradient in male mortality. Might these new technologies create a new gradient between seamen on ships built in countries with high levels of ecological development and others seamen? The vigilance of marine physicians around the world will highlight these new dynamics of public health. In our countries, the French Society of Maritime Medicine and the Spanish Society of Maritime Medicine are developing a program to evaluate occupational risks on board these new ships. Firstly, studies of new jobs will be carried out during the following years. Then, the medical follow-up will be oriented according to these risks' analyses. 


\section{REFERENCES}

1. Loddé B, Dewitte J-D, Jeegaden D, Misery L (eds). Traité de médecine maritime. Lavoisier, Paris 2016.

2. Bovenzi M, Stanta G, Antiga G, et al. Occupational exposure and lung cancer risk in a coastal area of northeastern Italy. Int Arch Occup Environ Health. 1993; 65(1): 35-41, doi: 10.1007/bf00586056, indexed in Pubmed: 8354573.

3. Kirkeleit J, Riise T, Bråtveit M, et al. Increased risk of acute myelogenous leukemia and multiple myeloma in a historical cohort of upstream petroleum workers exposed to crude oil. Cancer Causes
Control. 2008; 19(1): 13-23, doi: 10.1007/s10552-007-9065-x, indexed in Pubmed: 17906934.

4. Loddé $B$, Lucas $D$, Letort JM, et al. Acute phosphine poisoning on board a bulk carrier: analysis of factors leading to a fatal case. JOccup Med Toxicol. 2015;10:10, doi:10.1186/s12995-015-0050-0, indexed in Pubmed: 25763098.

5. Roberts SE, Carter T. British merchant seafarers 1900-2010: A history of extreme risks of mortality from infectious disease. Travel Med Infect Dis. 2016; 14(5): 499-504, doi: 10.1016/j. tmaid.2016.06.009, indexed in Pubmed: 27395763. 